\title{
Impact of Sacrospinous Colpopexy Associated with Anterior Colporrhaphy for the Treatment of Dome Prolapse on all Three Vaginal Compartments
}

\section{Resultados da colpofixação sacroespinal associada a colporrafia anterior para o tratamento do prolapso de cúpula vaginal}

\author{
Edilson Benedito de Castro ${ }^{1}$ Cássia Raquel Teatin Juliato ${ }^{1}$ Luciana Alonso Salão Piedemonte ${ }^{1}$ \\ Luiz Carlos dos Santos Júnior ${ }^{1}$ \\ ${ }^{1}$ Department of Gynecology and Obstetrics, Universidade Estadual de \\ Campinas, Campinas, SP, Brazil \\ Rev Bras Ginec Obst 2016;38:77-81. \\ Address for correspondence Edilson Castro, Departamento de \\ Ginecologia, Centro de Atenção Integral a Saúde da Mulher, Rua \\ Alexander Flemming, 101 - Cidade Universitária Zeferino Vaz, \\ Campinas, SP, Brazil 13083-881 (e-mail: edilson.castro@uol.com.br).
}

\begin{abstract}
Keywords

- vaginal vault prolapse

- sacrospinous fixation

- POP-Q
\end{abstract}

Objective To evaluate the results of sacrospinous colpopexy surgery associated with anterior colporrhaphy for the treatment of women with post-hysterectomy vaginal vault prolapse.

Methods This prospective study included 20 women with vault prolapse, Pelvic Organ Prolapse Quantification System (POP-Q) stage $\geq 2$, treated between January 2003 and February 2006, and evaluated in a follow-up review (more than one year later). Genital prolapse was evaluated qualitatively in stages and quantitatively in centimeters. Prolapse stage $<2$ was considered to be the cure criterion. Statistical analysis was performed using the Wilcoxon test (paired samples) to compare the points and stages of prolapse before and after surgery.

Results Evaluation of the vaginal vault after one year revealed that $95 \%$ of subjects were in stage zero and that $5 \%$ were in stage 1 . For cystocele, $50 \%$ were in stage $1,10 \%$ were in stage 0 (cured) and $40 \%$ were in stage 2 . For rectocele, three women were in stage $1(15 \%)$, one was in stage $2(5 \%)$ and 16 had no further prolapse. The most frequent complication was pain in the right buttock, with remission of symptoms in all three cases three months after surgery.

Conclusions In this retrospective study, the surgical correction of vault prolapse using a sacrospinous ligament fixation technique associated with anterior colporrhaphy proved effective in resolving genital prolapse. Despite the low complication rates, there was a high rate of cystocele, which may be caused by posterior vaginal shifting due to either the technique or an overvaluation by the POP-Q system. received

June 1, 2015

accepted

November 10, 2015

published online

February 1, 2016
DOI http://dx.doi.org/

10.1055/s-0035-1571264. ISSN 0100-7203.
Copyright $@ 2016$ by Thieme Publicações License terms

Ltda, Rio de Janeiro, Brazil

(ㄷ) (i) $\ominus$ (\$) 


\section{Resumo}

\section{Palavras-chave \\ - prolapso cúpula vaginal \\ - fixação sacroespinal \\ - POP-Q}

Objetivo Avaliar os resultados da cirurgia de colpofixação sacroespinal associada a colporrafia anterior, para o tratamento de mulheres com prolapso de cúpula vaginal pós-histerectomia.

Métodos Estudo prospectivo que incluiu 20 mulheres com prolapso de cúpula em estágio $\geq 2$ de acordo com o Sistema de Quantificação do Prolapso Genital (POP-Q) tratadas no período de janeiro de 2003 a fevereiro de 2006 e avaliadas em revisão tardia (maior que um ano). O prolapso genital foi avaliado qualitativamente em estágios e, quantitativamente, em centímetros. Como critério de cura, consideramos prolapso em estágio $<2$. Para análise estatística, foi utilizado teste de Wilcoxon (amostras pareadas) para comparar os pontos e estágios dos prolapsos antes e depois da cirurgia.

Resultados Na cúpula vaginal a avaliação após um ano mostrou $95 \%$ em estágio zero e $5 \%$ em estágio 1. Cistocele: $50 \%$ em estágio 1, 10\% em estágio zero (curadas) e $40 \%$ em estágio 2. Retocele: três mulheres apresentavam estágio 1 (15\%), uma em estágio 2 (5\%) e dezesseis não apresentavam prolapso posterior. As complicações mais frequentes foram dor no glúteo direito com remissão do sintoma em todos os três casos após três meses da cirurgia.

Conclusões Neste estudo retrospectivo, a cirurgia de correção do prolapso de cúpula pela técnica de fixação no ligamento sacroespinal, associada à colporrafia anterior, se mostrou efetiva na resolução do prolapso genital com baixa taxa de complicações; porém com alta taxa de cistocele - o que pode ter sido decorrente do desvio vaginal posterior pela técnica, ou ainda uma supervalorização pelo sistema POP-Q.

\section{Introduction}

The pelvic viscera are supported by two main mechanisms: the endo-pelvic fascia and its condensations (the vesicovaginal fascia, the rectovaginal septum, the utero-sacral ligament, and the cardinal ligament) and the pelvic diaphragm (the levator ani muscles and the coccyx). Vaginal vault prolapse is caused by a weakening of the cardinal and uterosacral ligaments. ${ }^{1,2}$

The incidence of post-hysterectomy vaginal vault prolapse is unknown but has been estimated at 2.0 to 3.6:1000 person-years. When there is some type of associated dystopia, vault prolapse rates are higher, reaching 15:1000 person-years in patients whose hysterectomy indication was uterine prolapse. ${ }^{3,4}$ In the gynecology and obstetrics department at the Centro de Atenção Integral à Saúde da Mulher (Women's Health Comprehensive Care Center - CAISM), Universidade Estadual de Campinas (Unicamp), the posthysterectomy prolapse rate was $\sim 3.4: 1000$ for hysterectomies performed between January 1986 and May 1991. ${ }^{5}$

There are three main interrelated objectives in the treatment of vaginal vault and uterine prolapse: correcting the anatomical defect, restoring sexual function, and restoring or maintaining intestinal and urinary functions. ${ }^{6}$ Other important medical team goals include improving quality of life and preventing recurrence of the prolapse. ${ }^{2,7}$

There are several surgical techniques available for the treatment of vaginal vault prolapse, including abdominal sacral colpopexy and vaginal sacrospinous fixation. In an article published by the Cochrane Library Incontinence
Review Group ${ }^{8}$ that included three prospective randomized studies, abdominal sacral colpopexy was better than vaginal sacrospinous colpopexy, with lower recurrence rates of vaginal prolapse and dyspareunia. There was no significant difference in surgical re-intervention rates between these dystopias. However, sacrospinous colpopexy had a lower cost, shorter operative time, and provided a faster return to daily activities. ${ }^{8}$

There is a wide variation in the published failure rates for sacrospinous ligament colpopexy, which is explained in part by the choice of method for analyzing the anatomical result and by which vaginal compartments are being considered; however, recurrence appears to be more frequent in the anterior vaginal compartment. ${ }^{2,9,10}$

In a recent systematic review evaluating sacrospinous ligament colpopexy for the treatment of uterine and vaginal vault prolapse, a very high recurrence rate was found for the anterior vaginal wall, reaching $43.8 \% .{ }^{11}$ Concomitant treatment of the anterior wall can be effective in these women. Therefore, the aim of the present study was to determine the genital prolapse rate after sacrospinous colpopexy surgery associated with anterior colporrhaphy in women who had previously undergone hysterectomy.

\section{Methods}

This prospective study evaluated 20 women with post-hysterectomy vaginal vault prolapse and undergoing sacrospinous colpopexy surgery associated with anterior colporrhaphy in the Hospital Estadual de Sumaré da 
Universidade Estadual de Campinas between 2003 and 2006. Inclusion criteria were vaginal vault prolapse after hysterectomy stage $\geq 2$ and vaginal length greater than $8 \mathrm{~cm}$. Exclusion criteria were history of gynecological cancer, rectosigmoid surgery, previous vaginal vault prolapse repair surgery, and vaginal stenosis. The women had their prolapses evaluated before surgery and every six months after surgery, with a mean follow-up of 30 months ( 14.4 to 48 months) by means of the genital prolapse quantification system (POPQ). ${ }^{12}$

The surgical technique employed was vaginal vault fixation onto the right sacrospinous ligament using blunt digital dissection of the ipsilateral ischiorectal fossa with an approach via the posterior vaginal compartment. Two polygalactin-0 sutures were placed on the right sacrospinous ligament by means of direct visualization, and the vaginal vault was repaired, followed by anterior wall colporrhaphy with polygalactin-0 sutures. Women who had posterior genital prolapse underwent site-specific correction during surgery.

We performed statistical analysis using SAS Version 8.2 for Windows, SAS Institute Inc., Cary, North Carolina, and used the Wilcoxon test to compare the points and stages of genital prolapse before and after surgery. Intra- and postoperative complications are described using simple frequencies. All patients signed terms of free and informed consent. The study was approved by the Ethics Committee of the Faculty of Medical Sciences, Unicamp.

\section{Results}

The patients' mean age was 61.2 years (50-80). Parity ranged from 1 to 11 (average of 4.2 births), and no participant had previous cesarean delivery. Of the twenty patients undergoing surgery, $13(65 \%)$ had histories of total abdominal hysterectomy, 7 (35\%) had histories of total vaginal hysterectomy, and 12 (60\%) had histories of previous anterior and posterior colporrhaphy (-Table 1 ).

Only one of the 20 women included had no cystocele. Eight (40\%) out of 20 had paravaginal cystocele defects, and 11 (55\%) had central defects. Rectocele was present in five cases (25\%), and enterocele was present in 12 cases (60\%).

Table 1 Sample description: demographic characteristics of the sample and prior surgeries

\begin{tabular}{|l|l|l|}
\hline & Mean & Variation \\
\hline Age & 61.7 & $50-80$ \\
\hline Parity & 3.8 & $1-11$ \\
\hline Normal birth & 3.7 & $1-11$ \\
\hline Total hysterectomy & 12 & - \\
\hline Vaginal hysterectomy & 7 & - \\
\hline Subtotal hysterectomy & 1 & - \\
\hline Anterior colporrhaphy anterior & 8 & - \\
\hline Perineorrhaphy & 8 & - \\
\hline
\end{tabular}

Before surgery, five women presented stage 2 vaginal vault prolapse (25\%), 12 were in stage $3(60 \%)$ and three were in stage 4 (15\%). In the follow-up review, only one presented stage 1 prolapse (5\%), and 19 showed no apical prolapse (95\%), with $p<0.0001$ (-Table 1). The cure rate for the vaginal apex was $100 \%$ with the technique used (95\% stage zero and $5 \%$ stage 1 ).

Regarding the anterior wall, we identified two women (10\%) with stage 1 cystocele, two with stage $2(10 \%)$, thirteen with stage $3(65 \%)$ and three with stage 4 (15\%) prior to surgery, versus ten in stage 1 (50\%), eight in stage 2 (40\%) and two $(10 \%)$ without cystocele after surgery $(p<0.0001)$ ( - Table 2 ). Of the 18 women with stage $\geq 2$ prior prolapse, $10(55.5 \%)$ still had prolapse at this stage.

Regarding the posterior vaginal compartment before surgery, we identified four patients with stage 2 rectocele (20\%), thirteen with stage 3 (65\%), and three with stage 4 (15\%). In the follow-up review after surgery, three women had stage 1 rectocele (15\%), one had stage $2(5 \%)$, and 16 showed no subsequent prolapse $(p<0.0001)$ ( $($ Table 1$)$. Of the 20 women with posterior wall prolapse, one (5\%) was not cured.

The mean POP-Q points before and after the surgery, respectively, were as follows: Aa (point $\mathrm{A}$ of anterior wall) $+0.4 /-1.55(p=0.0002)$, Ba (point B of anterior wall) $+3 /-$ $1.55(p<0.0001), \quad$ C (cervical point) $+3.05 /-7.75$ $(p<0.0001)$, Ap (point A of posterior wall) $+0.05 /-2.75$ $(p<0.0001), \mathrm{Bp}$ (point $\mathrm{B}$ of posterior wall) $+3.2 /-2.75$ ( $p<0.0001)$, GH (genital hiatus) 3.4/2.1 $(p<0.0001)$, PB (perineal body) $2.4 / 2.95(\mathrm{p}=0.0156)$ and TVL (total vaginal length) $8.6 / 7.85(\mathrm{p}=0.0002)$ (-Table 3 ).

Table 2 Stage, according to POP-Q ${ }^{12}$ classifications of apical, anterior, and posterior prolapses before and after surgical intervention

\begin{tabular}{|l|l|l|}
\hline POP-Q stage & Pre-operative & Post-operative \\
\hline Apical & $\%$ & $\%$ \\
\hline Stage 0 & 0 & $95.0^{*}$ \\
\hline Stage 1 & 0 & 5.0 \\
\hline Stage 2 & 25.0 & 0 \\
\hline Stage 3 & 60.0 & $0^{*}$ \\
\hline Stage 4 & 15.0 & 0 \\
\hline Anterior & & \\
\hline Stage 0 & 0 & 10.0 \\
\hline Stage 1 & 10.0 & $50.0^{*}$ \\
\hline Stage 2 & 10.0 & $40.0^{*}$ \\
\hline Stage 3 & 65.0 & $0^{*}$ \\
\hline Stage 4 & 15.0 & 0 \\
\hline Posterior & & \\
\hline Stage 0 & 0 & $80.0^{*}$ \\
\hline Stage 1 & 0 & 15.0 \\
\hline Stage 2 & 20.0 & 5.0 \\
\hline Stage 3 & 65.0 & $0^{*}$ \\
\hline 0.05 & \\
\hline
\end{tabular}

${ }^{*} \mathrm{p}<0.05$. 
Table 3 Comparison between pre- and post-operative anatomical points according to POP-Q ${ }^{12}$ classifications

\begin{tabular}{|l|l|l|l|}
\hline POP-Q points & Pre-operative & Post-operative & \\
\hline $\mathrm{Aa}$ & +0.4 & -1.55 & ${ }^{* *}$ \\
\hline $\mathrm{Ba}$ & +3 & -1.55 & ${ }^{* *}$ \\
\hline $\mathrm{C}$ & +3.05 & -7.75 & ${ }^{* *}$ \\
\hline $\mathrm{Ap}$ & +0.05 & -2.75 & ${ }^{* *}$ \\
\hline $\mathrm{Bp}$ & +3.2 & -2.75 & ${ }^{* *}$ \\
\hline $\mathrm{GH}$ & 3.4 & 2.1 & ${ }^{* *}$ \\
\hline $\mathrm{PB}$ & 2.4 & 2.95 & ${ }^{* *}$ \\
\hline $\mathrm{TVL}$ & 8.6 & 7.85 & - \\
\hline
\end{tabular}

Abbreviations: Aa, point $A$ of anterior wall; $A p$, point $A$ of posterior wall; $B a$ point $B$ of anterior wall; $B$ p, point $B$ of posterior wall; $C$, cervical point; $\mathrm{GH}$, genital hiatus (in cm); PB, perineal body (in cm); POP-Q, Genital Prolapse Quantification System; TVL, total vaginal length (in $\mathrm{cm}$ ).

Points according to POP-Q classifications.

** $\mathrm{p}<0.05$.

There were no vascular, intestinal, or urinary tract lesions in this group. None of the women who underwent surgery presented infections at the surgical site. The most frequent complication was pain in the right buttock, with remission of symptoms in all three cases three months after surgery.

\section{Discussion}

In the present study, surgical repair of vaginal prolapse using the sacrospinous ligament fixation technique associated with anterior colporrhaphy proved to be effective in curing vaginal vault prolapse, with a low rate of complications but with a high rate of cystocele (prolapsed anterior wall), with stage 1 or 0 as the criterion for vaginal prolapse cure. The choice for this cure criterion was based on the fact that symptoms are rare in women with early prolapse, who are most often symptomatic from the hymen (stage 2).

The high apical prolapse cure rates obtained in the present study are consistent with the literature. ${ }^{13}$ Colpopromontofixation has been accepted as the gold standard for apical prolapse treatment. In a systematic review, the objective success rate of colpopromontofixation with stage $<2$ prolapse in POP-Q was superior to the rate for sacrospinous ligament fixation. ${ }^{14}$ However, this same study showed a similar rate of objective cure between the two techniques, enabling us to infer that the two surgeries are effective forms of apical prolapse treatment. This inference is in agreement with the findings of the present study.

The main issue with colpopexy to the sacrospinous ligament is cystocele (anterior wall prolapse), likely due to the posterior shift of the vaginal axis. ${ }^{15-17}$

The present study showed an anterior wall failure rate (cystocele) of 55.5\%, which is consistent with the findings of a randomized controlled prospective study that evaluated the results of anterior colporrhaphy versus the use of a synthetic fabric after two years of follow-up. ${ }^{18}$ The study showed cystocele failure rates of $58 \%$ in the colporrhaphy group and $18 \%$ when synthetic fabric was used. ${ }^{18}$

The anatomical superiority of the use of synthetic fabric is well described in the literature. Other studies have also shown the superiority of synthetic fabric for the correction of anterior wall prolapse. $2,19,20$

Recently, however, the U.S. Food and Drug Administration (FDA) published warnings related to risks associated with the use of synthetic vaginal fabrics. ${ }^{21}$ The most frequently reported adverse event is mesh extrusion, which may may present severe disorders if any adjacent organ is involved. Because of this possibility, fixation to the sacrospinous ligament, which is a standard procedure, again became interesting because it does not require fabric attachment. In this sense, anterior colporrhaphy to avoid increasing the anterior prolapse would also be interesting.

A previous study suggests that when vaginal length is maintained and site-specific correction of the cystocele is performed, the recurrence of anterior vaginal wall prolapse would be reduced. ${ }^{22}$ However, we did not observe this effect in our study. Our findings allow us to state that cystocele is common in women undergoing correction with sacrospinous fixation and that colporrhaphy is not effective in preventing this complication.

Colpopexy onto the sacrospinous ligament for the treatment of vault prolapse is commonly used in vaginal surgery and became popular in Europe and the United States in the $1970 s^{2,23}$ This procedure results in low morbidity and reports of vascular lesions and hemorrhages are rare. ${ }^{24}$ The findings of the present study corroborate the literature findings, with no serious adverse events observed in the study's case series.

The present study is limited by the small number of patients and the short follow-up of two years. Studies with a larger sample size and a longer follow-up of 5 years are needed, which should not only include objective evaluation performed by the surgeon via POP-Q, but also subjective evaluations via quality of life questionnaires. Some studies have questioned the use of the POP-Q classification. Lack of success tends to be related to the absence of symptoms rather than to anatomical cure shown by POP-Q. ${ }^{25}$

Nevertheless, the strength of the present study is that the population was homogeneous, as we included only women with vaginal vault prolapse.

\section{Conclusion}

We conclude that surgical repair of vaginal prolapse via the sacrospinous ligament fixation technique is effective for the treatment of apical vault prolapse but with high rates of cystocele, which are not prevented by performing colporrhaphy concomitant to surgical treatment.

\section{References}

1 DeLancey JO. Anatomic aspects of vaginal eversion after hysterectomy. Am J Obstet Gynecol 1992;166(6 Pt 1):1717-1724, discussion 1724-1728 
2 Lo TS, Tan YL, Khanuengkitkong S, Dass AK. Surgical outcomes of anterior trans-obturator mesh and vaginal sacrospinous ligament fixation for severe pelvic organ prolapse in overweight and obese Asian women. Int Urogynecol J 2013;24(5):809-816

3 Mant J, Painter R, Vessey M. Epidemiology of genital prolapse: observations from the Oxford Family Planning Association Study. Br J Obstet Gynaecol 1997;104(5):579-585

4 Richter K. Massive eversion of the vagina: pathogenesis, diagnosis, and therapy of the "true" prolapse of the vaginal stump. Clin Obstet Gynecol 1982;25(4):897-912

5 Simões JA, Giraldo PC, França ST, Bedone AJ, Souza GA. [Surgical correction of post-histerectomy vaginal vault prolapse: a retrospective analysis]. Rev Bras Ginecol Obstet 1992;14(5):220-223 Portuguese

6 Shull BL, Capen CV, Riggs MW, Kuehl TJ. Preoperative and postoperative analysis of site-specific pelvic support defects in 81 women treated with sacrospinous ligament suspension and pelvic reconstruction. Am J Obstet Gynecol 1992;166(6 Pt 1):1764-1768, discussion 1768-1771

7 Klauschie JL, Cornella JL. Surgical treatment of vaginal vault prolapse: a historic summary and review of outcomes. Female Pelvic Med Reconstr Surg 2012;18(1):10-17

8 Maher C, Baessler K, Glazener CM, Adams EJ, Hagen S. Surgical management of pelvic organ prolapse in women. Cochrane Database Syst Rev 2007;(3):CD004014

9 Larson KA, Smith T, Berger MB, et al. Long-term patient satisfaction with michigan four-wall sacrospinous ligament suspension for prolapse. Obstet Gynecol 2013;122(5):967-975

10 Morgan DM, Larson K. Uterosacral and sacrospinous ligament suspension for restoration of apical vaginal support. Clin Obstet Gynecol 2010;53(1):72-85

11 Tseng LH, Chen I, Chang SD, Lee CL. Modern role of sacrospinous ligament fixation for pelvic organ prolapse surgery-a systemic review. Taiwan J Obstet Gynecol 2013;52(3):311-317

12 Bump RC, Mattiasson A, Bø K, et al. The standardization of terminology of female pelvic organ prolapse and pelvic floor dysfunction. Am J Obstet Gynecol 1996;175(1):10-17

13 Mothes AR, Wanzke L, Radosa MP, Runnebaum IB. Bilateral minimal tension sacrospinous fixation in pelvic organ prolapse: an observational study. Eur J Obstet Gynecol Reprod Biol 2015; 188:1-5

14 Barber MD, Maher C. Apical prolapse. Int Urogynecol J 2013;24(11):1815-1833
15 Morgan DM, Rogers MAM, Huebner M, Wei JT, Delancey JO. Heterogeneity in anatomic outcome of sacrospinous ligament fixation for prolapse: a systematic review. Obstet Gynecol 2007; 109(6):1424-1433

16 Benedito de Castro E, Palma P, Riccetto C, Herrmann V, Bigozzi MA, Olivares JM. [Impact of sacrospinous vaginal vault suspension on the anterior compartment]. Actas Urol Esp 2010;34(1):106-110 Spanish

17 Maher CF, Qatawneh AM, Dwyer PL, Carey MP, Cornish A, Schluter PJ. Abdominal sacral colpopexy or vaginal sacrospinous colpopexy for vaginal vault prolapse: a prospective randomized study. Am J Obstet Gynecol 2004;190(1):20-26

18 Menefee SA, Dyer KY, Lukacz ES, Simsiman AJ, Luber KM, Nguyen JN. Colporrhaphy compared with mesh or graft-reinforced vaginal paravaginal repair for anterior vaginal wall prolapse: a randomized controlled trial. Obstet Gynecol 2011;118(6):1337-1344

19 Altman D, Väyrynen T, Engh ME, Axelsen S, Falconer C; Nordic Transvaginal Mesh Group. Anterior colporrhaphy versus transvaginal mesh for pelvic-organ prolapse. N Engl J Med 2011;364(19):1826-1836

20 Lamblin G, Van-Nieuwenhuyse A, Chabert P, Lebail-Carval K, Moret S, Mellier G. A randomized controlled trial comparing anatomical and functional outcome between vaginal colposuspension and transvaginal mesh. Int Urogynecol J 2014;25(7): 961-970

21 United States. Food and Drug Administration [Internet]. Urogynecologic surgical mesh: update on the safety and effectiveness of transvaginal placement for pelvic organ prolapse. Jul 2011. Available at: http://www.fda.gov/downloads/MedicalDevices/ Safety/AlertsandNotices/UCM262760.pdf. Accessed on Sep 7, 2015

22 Smilen SW, Saini J, Wallach SJ, Porges RF. The risk of cystocele after sacrospinous ligament fixation. Am J Obstet Gynecol 1998;179(6 Pt 1):1465-1471, discussion 1471-1472

23 Demirci F, Demirci O, Dolgun ZN, et al. Perioperative complications in abdominal sacrocolpopexy, sacrospinous ligament fixation and prolift procedures. Balkan Med J 2014;31(2):158-163

24 Diwadkar GB, Barber MD, Feiner B, Maher C, Jelovsek JE. Complication and reoperation rates after apical vaginal prolapse surgical repair: a systematic review. Obstet Gynecol 2009;113(2 Pt 1): 367-373

25 Barber MD, Brubaker L, Nygaard I, et al; Pelvic Floor Disorders Network. Defining success after surgery for pelvic organ prolapse. Obstet Gynecol 2009;114(3):600-609 